\title{
Platinum-rhodium-tin/carbon electrocatalysts for ethanol oxidation in acid media: Effect of the precursor addition order and of the tin amount
}

\author{
F.E. López-Suárez ${ }^{a^{*}}$, M. Perez-Cadenas ${ }^{b}$, A. Bueno-López ${ }^{c}$, C.T Carvalho-Filho ${ }^{a}$ \\ K.I.B. Eguiluz ${ }^{a}$, G.R Salazar-Banda ${ }^{a}$.
}

${ }^{a}$ Electrochemistry and Nanotechnology Laboratory, Research and Technology Institute I

Processes Engineering Post-graduation - PEP, Universidade Tiradentes, Av. Murilo Dantas, 300, Aracaju, SE, Brazil.

${ }^{b}$ Department of Inorganic Chemistry and Technical, UNED, Faculty of Sciences, Senda del Rey $n^{\circ}$ 9, 28040 Madrid, Spain.

${ }^{\mathrm{c}}$ MCMA group, Department of Inorganic Chemistry, Faculty of Sciences, University of Alicante, Ap. 99 E-03080, Alicante, Spain.

\section{Emails:}

F.E. López-Suárez: franzedwin@gmail.com M. Perez-Cadenas: mariaperez@ccia.uned.es
A. Bueno-López: agus@ua.esa
C.T Carvalho-filho: trivellatoc@hotmail.com
K.I.B. Eguiluz: katlin.eguiluz@pq.cnpq.br
G.R Salazar-Banda: gianrsb@gmail.com

* Corresponding author: email: franzedwin@gmail.com

Tel. +55 079-3218-2115

Fax. +55 079-32182190 


\section{ABSTRACT}

Carbon-supported $\mathrm{Pt}_{x}-\mathrm{Rh}_{y}-\mathrm{Sn}_{z}$ catalysts $(x: y: z=3: 1: 4,6: 2: 4,9: 3: 4)$ are prepared by $\mathrm{Pt}$, Rh and Sn precursors reduction in different addition order. The materials are characterized by X-ray diffraction, transmission electron microscopy and X-ray photoelectron spectroscopy techniques and are evaluated for the electrooxidation of ethanol in acidic media by cyclic voltammetry, chronoamperometry and anode potentiostatic polarization.. Oxidized Rh species prevail on the surface of catalysts synthetized by simultaneous co-precipitation, thus demonstrating the influence of synthesis method on the oxidation state of catalysts. Furthermore, high amounts of Sn in composites synthetized by co-precipitation results in very active catalysts at low potentials (bifunctional effect) while medium Sn load is needed for sequentially deposited catalysts when the electronic effect is most important (high potentials), since more exposed Pt and Rh sites are needed on the catalyst surface to alcohol oxidation. The $\mathrm{Pt}_{3}-\mathrm{Rh}_{1}-\mathrm{Sn}_{4} / \mathrm{C}$ catalyst prepared by coprecipitation is the most active at potentials lower than $0.55 \mathrm{~V}$ (related to bifunctional effect) while the $\mathrm{Pt}_{6}-\mathrm{Rh}_{2}-\mathrm{Sn}_{4} / \mathrm{C}$ catalyst, prepared by sequential precipitation (first $\mathrm{Rh}$ and, after drying, $\mathrm{Pt}+\mathrm{Sn})$, is the most active above $0.55 \mathrm{~V}$.

Keywords: Platinum; Tin; Rhodium; Electrocatalysis; Fuel Cell.

\section{Introduction}


The electrocatalytic oxidation of small organic molecules to produce electrical energy by in low-temperature direct fuel cell has received increasing attention due to its advantages with regard to other technologies, such as, easy transportation and storage of the fuel, reduced weight, size and complexity, and high energy efficiency. Ethanol is an attractive fuel for this application if compared with methanol and hydrogen, because it is less toxic, is available from renewable resources, and is easily stored and transported. However, the slow and inefficient alcohol oxidation on the available electrocatalysts is a handicap for direct ethanol fuel cells commercialization [1,2]. Platinum is the best catalyst for the adsorption and dissociation of small organic molecules, but the activity for total electro-oxidation (12 $\mathrm{e}^{-}$per molecule) of ethanol to $\mathrm{CO}_{2}$ is poor because, i) $\mathrm{C}-\mathrm{C}$ bond cleavage is difficult and, ii) the oxidation rate of adsorbed reaction intermediates $\left(\mathrm{CH}_{3} \mathrm{CHO}\right.$ and $\mathrm{CH}_{3} \mathrm{COOH}$ ) is slow [3-5].

Bimetalic catalysts can improve the behavior of Pt-only electrocatalysts [6,7]. Pt-Sn catalysts are generally considered the best anodes for ethanol oxidation, working at lower potentials than pure platinum [8-10]. Pt is the most active metal for alcohol oxidation in acid medium, and Sn provides surface oxygen species for the oxidation of $\mathrm{CO}$ and carbonyl species adsorbed on Pt, which are produced during the dissociative adsorption of ethanol on Pt active sites at low potentials [11-14]. The addition of Sn to Pt catalysts, although enhances the catalyst activity towards ethanol oxidation, cannot accelerate the $\mathrm{C}-\mathrm{C}$ bond cleavage rate.

De Souza et al. [3] found that bimetallic Pt-Rh electrodes decrease the acetaldehyde yield and increase the $\mathrm{CO}_{2}$ selectivity compared to pure platinum electrodes.[10]. However, the ethanol oxidation rate achieved with Pt-Rh catalysts [15] rate is lower than that of Pt-Sn [10]. Ternary PtRh-Sn electrocatalysts combine high oxidation rate with high $\mathrm{CO}_{2}$ selectivity and experimental and theoretical results demonstrate that the good performance of these ternary electrocatalysts is 
related to thesynergistic effect of Pt, $\mathrm{Rh}$ and Sn [16,17,10,18-20,15]. Pt provides the active sites for the first reaction step, that is, the adsorption and dehydrogenation of ethanol. Rh plays the main role decreasing the formation of acetaldehyde [21] and $\mathrm{SnO}_{2}$ strongly adsorbs $\mathrm{H}_{2} \mathrm{O}$ under electrochemical conditions, which provides $\mathrm{OH}^{-}$for oxidation of $\mathrm{CO}$ adsorbed over $\mathrm{Rh}$ or $\mathrm{Pt}$, keeping Pt and Rh available for further ethanol oxidation [22,18,23,24].

Recent efforts have been concentrated on ternary Pt-Rh-Sn [16,17,10,18-20,15]. The preparation method is critical in order to achieve the desired activity, selectivity and life-time of these systems $[15,25]$. The synthesis strategies play a determining role in the catalyst properties including morphology, textures and forms, activity and stability, among others. For instance, Koval et al. $[18,20]$ synthesized Pt- $\mathrm{Rh}-\mathrm{SnO}_{2}$ nanoclusters supported on high-area carbon, with an optimum Pt:Rh:Sn atomic ratio of 3:1:4, by cation-adsorption/reduction-galvanic-displacement method. These catalysts showed to be very effective in $\mathrm{C}-\mathrm{C}$ ethanol bond splitting at room temperature in acid solution and facilitate its oxidation to $\mathrm{CO}_{2}$ at low potentials through oxametallacyclic conformation.

$\mathrm{Pt}_{52} \mathrm{Sn}_{(36-x)} \mathrm{Rh}_{12}-\mathrm{Sn}_{x} \mathrm{O}_{2 x}$ catalysts synthesized using a polyol process, with the coexistence of homogeneously distributed $\mathrm{Pt} / \mathrm{Sn} / \mathrm{Rh}$ random alloy and non-alloyed $\mathrm{SnO}_{2}$ throughout the catalyst, possessed a superior long-term activity and stability towards ethanol oxidation than the commercial Pt catalyst [15]. Song et al. [16] reported a two-steps synthesis of $\mathrm{PtSnO} \mathrm{O}_{2} @ \mathrm{Rh} / \mathrm{C}$ catalysts by a modified pulse microwave-assisted polyol method followed by heat treatment, achieving an enhanced performance. They found that the as-obtained $\mathrm{PtSnO}_{2} @ \mathrm{Rh} / \mathrm{C}$ catalyst exhibited high activity not only towards ethanol electrooxidation, but also towards further oxidation of its intermediate products (i.e. acetaldehyde and acetic acid).

Colmati et al. [10] synthesized carbon-supported ternary Pt-Sn-Rh (1:1:0.3 and 1:1:1) alloy catalysts by reduction of the metal precursors with formic acid concluding that, for potentials 
higher than $0.45 \mathrm{~V}$ (versus reversible hydrogen electrode - RHE), the ternary Pt-Sn-Rh alloy catalysts possess the highest activity for ethanol electrooxidation, while for potentials lower than $0.45 \mathrm{~V}$ (vs RHE) the electrochemical activity of the ternary catalysts was lower than that of the binary Pt-Sn catalyst.

Therefore, the development of electrocatalysts for ethanol oxidation to $\mathrm{CO}_{2}$ is a major challenge in electrocatalysis. In this study, the effect of Pt-Rh-Sn electrocatalysts composition was investigated together with the effect of the Pt, Rh and Sn addition order on the EOR activity,. Six $\mathrm{Pt}_{x}-\mathrm{Rh}_{y}-\mathrm{Sn}_{z} / \mathrm{C}$ catalysts were prepared using co-precipitation reduction method and formic acid as reducing agent. The Pt:Rh atomic ratio was constant and Sn content was modified. The structure and morphology of the catalysts were studied by X-ray diffraction (XRD), X-ray photoelectron spectroscopy (XPS) and transmission electron microscopy (TEM). The electrochemical properties, as well as the catalytic activity were evaluated using cyclic voltammetry (CV), chronoamperometry (CA) and quasi-stationary potentiostatic polarization.

\section{Experimental}

\subsection{Preparation of catalysts}

$\mathrm{Pt}_{x}-\mathrm{Rh}_{y}-\mathrm{Sn}_{z} / \mathrm{C}$ electrocatalysts were prepared with $20 \%$ noble metal loading and XC-72 carbon black support (Cabot Cop., $240 \mathrm{~m}^{2} \mathrm{~g}^{-1}$ ). $\mathrm{Pt}_{x}-\mathrm{Rh}_{y}-\mathrm{Sn}_{z} / \mathrm{C}$ catalysts with different atomic ratios ( $x: y: z=3: 1: 4,6: 2: 4,9: 3: 4)$ were prepared by reduction of $\mathrm{Pt}$, Rh and Sn precursors through: i) sequential reductive precipitation (two-steps sequence), first adding $\mathrm{Rh}$ and then $\mathrm{Pt}$ and $\mathrm{Sn}$ (called $\mathrm{Pt}_{x}-\mathrm{Rh}_{y}-\mathrm{Sn}_{z} / \mathrm{C}-(\mathrm{S})$ ) and, ii) Pt and Sn were co-precipitated in one step (called $\mathrm{Pt}_{x}-\mathrm{Rh}_{y}-$ $\left.\mathrm{Sn}_{z} / \mathrm{C}-(\mathrm{T})\right) .3: 1$ ratio of $\mathrm{Pt}: \mathrm{Rh}$ was fixed in this study, based on results presented in previous reports $[18,3]$ where it was established that higher Pt content with regard to Rh facilitates the $\mathrm{C}-\mathrm{C}$ 
bond breaking on this system. Further reasons for using less Rh than Pt are that Rh alone is inactive for ethanol oxidation, and that it is even more expensive than Pt.

Catalysts were synthesized by a precipitation method using formic acid as reducing agent $[26,27]$. For catalysts prepared in a two-step sequence, $\mathrm{Rh} / \mathrm{C}$ was firstly obtained by the following procedure. The carbon support was added to a $2 \mathrm{M}$ formic acid solution and heated to $85^{\circ} \mathrm{C}$, and then an appropriate amount of $\mathrm{RhCl}_{3} \cdot x \mathrm{H}_{2} \mathrm{O}$ was added and mixed with the solution and the slurry was maintained at $85^{\circ} \mathrm{C}$ for 6 hours. The suspension was cooled down to room temperature, and the powder was recovered by filtration, washed with ultrapure water until no chloride ions could be detected, and dried at $60^{\circ} \mathrm{C}$. This process was repeated afterwards with $\mathrm{Rh} / \mathrm{C}$ and using $\mathrm{H}_{2} \mathrm{PtCl}_{6} \cdot 6 \mathrm{H}_{2} \mathrm{O}$ and $\mathrm{SnCl}_{2} \cdot 3 \mathrm{H}_{2} \mathrm{O}$ as $\mathrm{Pt}$ and Sn precursors (Sigma Aldrich, purity > 98\%), respectively. Whilst for catalysts prepared in a one step, Pt and Sn precursors were added together with $\mathrm{Rh} / \mathrm{C}$ already prepared.

\subsection{Catalysts characterization}

The crystalline structure was determined by XRD in a Seifert powder diffractometer using $\mathrm{CuK} \alpha$ radiation $(0.15418 \mathrm{~nm})$. The diffractograms were registered at $2 \theta$ angles from 10 to $90^{\circ}$, with a step of $0.02^{\circ}$ and a time per step of 3 seconds. The working conditions of the powder diffractometer were $1600 \mathrm{~kW}$, a tension of $40 \mathrm{kV}$ and a current of $40 \mathrm{~mA}$.

XPS characterization was carried out in a VG-Microtech Multilab 3000 electron spectrometer using Mg-Ka (1253.6 eV) radiation. To obtain the XPS spectra, the pressure of the analysis chamber was maintained at $5 \cdot 10^{-10}$ mbar and the binding energy (BE) scale was adjusted by setting the C1s transition to $284.6 \mathrm{eV}$.

Transmission electron microscopy images were obtained using a JEOL (JEM-2010) microscope at $200 \mathrm{kV}$. A few droplets of an ultrasonically-dispersed suspension of each catalyst in 
ethanol were deposited on a copper grid with lacey carbon film and dried at ambient conditions for TEM characterizations. Particle size distributions were determined by using 200 particles for each catalyst.

\subsection{Electrochemical measurements}

Electrochemical measurements were performed at room temperature using an Autolab Model PGSTAT 302N potentiostat/galvanostat. Experiments were carried out in a glass cell (one compartment) using a conventional three-electrode configuration (half-cell). The electrocatalyst was ultrasonically mixed with isopropyl alcohol (1 ml) and $30 \mu \mathrm{l} \mathrm{Nafion}{ }^{\circledR}$ solution (5 wt.\% Aldrich solution) to form an uniform ink. Then, $5 \mu \mathrm{l}$ of catalyst suspension was dropped onto a polished glassy carbon (GC) disk to form a homogenous thin catalyst layer. The reference system consisted of a hydrogen electrode in the same solution (HESS) connected by a Luggin capillar, and a Pt coil $\left(0.25 \mathrm{~cm}^{2}\right)$ was used as the counter-electrode. All potentials were referred to the reversible hydrogen electrode (RHE). Nitrogen gas was bubbled through all solutions for 15 min before starting each electrochemical test.

Electrochemical activity tests were performed at room temperature in aqueous $0.5 \mathrm{M} \mathrm{H}_{2} \mathrm{SO}_{4}$ solutions containing $0.5 \mathrm{M} \mathrm{C}_{2} \mathrm{H}_{5} \mathrm{OH}$. Cyclic voltammetry experiments were performed between 0.0 and $0.8 \mathrm{~V}$ until stationary responses were obtained. Then, two voltammetric cycles were performed between 0.0 and $1.0 \mathrm{~V}$ at $0.02 \mathrm{~V} \mathrm{~s}^{-1}$ to evaluate the behavior of each electrocatalyst. Chronoamperometric experiments were performed at $0.5 \mathrm{~V}$ and anode polarization curves were obtained between 0.2 and $0.8 \mathrm{~V}$ in the potentiostatic mode, with all data points obtained after 200 s of polarization at each potential. The current densities were obtained by dividing the obtained current (in Amperes) by the geometric area of glassy carbon disk (in square centimeter) and per the amount of platinum present on catalyst (in grams). The tests were repeated for three times to 
check reproducibility.

The CO voltammetric stripping experiments were performed as follows. CO was adsorbed onto the electrode surface by bubbling high-purity $\mathrm{CO}$ through $0.5 \mathrm{M} \mathrm{H}_{2} \mathrm{SO}_{4}$ solution, while holding the electrode potential at $0.05 \mathrm{~V}$. After the adsorption period $(5 \mathrm{~min})$, the dissolved $\mathrm{CO}$ was removed from the solution by bubbling high-purity nitrogen through the solution for 30 min keeping the potential at $0.05 \mathrm{~V}$. The potential was then scanned in a positive direction from $0.05 \mathrm{~V}$ to $1.0 \mathrm{~V}$ at $0.01 \mathrm{~V} \mathrm{~s}^{-1}$.

\section{Results and discussion}

\subsection{Physico-chemical characterization of the electrocatalysts}

\subsubsection{XRD characterization}

Fig. 1a and 1b show the XRD patterns of the catalysts prepared in one and two steps, respectively. The diffraction peak at 20-25 degrees observed in all the diffraction patterns of the carbon-supported catalysts is attributed to the (002) plane of the hexagonal structure of Vulcan XC-72 carbon. The XRD patterns of all the catalysts show the characteristic peaks of the face centered cubic (fcc) crystalline Pt,with (111), (200), (220), and (311) planes appearing at the expected diffraction angles in good agreement with the Pt standard (JCPDS PDF 04-0802 reference included in Fig. 1). The diffraction peaks at $33^{\circ}$ and $51^{\circ}$ are assigned to $\mathrm{SnO}_{2}$ (101) and (211) planes, respectively, indicating that $\mathrm{Sn}$ has been introduced into $\mathrm{Pt}_{x}-\mathrm{Rh}_{y}-\mathrm{Sn}_{z} / \mathrm{C}$ catalysts as $\mathrm{SnO}_{2}$. No peaks of metallic $\mathrm{Rh}$ or $\mathrm{Rh}$ oxides were detected in the $\mathrm{Pt}_{x}-\mathrm{Rh}_{y}-\mathrm{Sn}_{z} / \mathrm{C}$ catalysts, but their presence cannot be discarded because they may be present in a very small particle size or even in an amorphous form. Moreover, Rh has very similar lattice parameters than Pt, and it is difficult to 
distinguish their peaks [19].

All diffraction peaks are broad, indicating a very small average crystallite size. The average Pt particles size was calculated from the Gaussian-fitted Pt (220) peak according to Scherrer's equation and the obtained values together with the lattice parameter are given in Table 1. Crystallite sizes in the $\sim 2.6-2.8 \mathrm{~nm}$ range were obtained for all $\mathrm{Pt}_{x}-\mathrm{Rh}_{y}-\mathrm{Sn}_{z} / \mathrm{C}$ catalysts. The lattice parameters of the ternary catalysts were larger than that of $\mathrm{Pt} / \mathrm{C}$ and all diffraction peaks shifted to lower $2 \theta$ values angles compared with $\mathrm{Pt} / \mathrm{C}$, further confirming the formation of a Pt containing alloy and interactions between Pt and other metals, Sn and Rh. However, the opposite effects on lattice contraction/expansion induced by Rh and Sn doping, as well as the peak broadening due to small size of the catalyst, hinders the analysis of the formation of any binary or ternary alloy between Pt, Sn and Rh. Finally, we can establish from XRD results that not major differences between the crystal structure and the preparation method were found among catalysts.

\subsubsection{TEM characterization}

All the catalysts were examined by TEM imaging. Fig. 2a-f shows the TEM images and the particle size distribution of $\mathrm{Pt}_{x}-\mathrm{Rh}_{y}-\mathrm{Sn}_{z} / \mathrm{C}$ prepared by two methodologies. The particle sizes, and the corresponding standard deviations, are included in Table 1.

TEM results show differences in morphology between catalysts prepared by the different procedure. When the Pt and Sn precursors are added together $\left(\mathrm{Pt}_{x}-\mathrm{Rh}_{y}-\mathrm{Sn}_{z} / \mathrm{C}-(\mathbf{T})\right)$ the density of particles increases, which seem to have coalesced to form small aggregates. However, for catalysts prepared by sequential impregnation $\left(\mathrm{Pt}_{x}-\mathrm{Rh}_{y}-\mathrm{Sn}_{z} / \mathrm{C}-(\mathbf{S})\right)$ small bright nanoparticles with nanospheres shape can be seen uniformly dispersed over the carbon support. No significant changes in the metal particle size due to the composition or preparation procedure was found, and its effect can be, therefore, ruled out in the interpretation of the electrocatalytic results. 


\subsubsection{XPS characterization}

XPS analysis provided information about catalyst surface composition. The oxidation states of Pt, Rh and Sn were studied by XPS following the Pt 4f, Rh $3 d$ and Sn 3p transitions, respectively. The Pt $4 f_{7 / 2}$ and $4 f_{5 / 2}$ spectra are shown in Fig. 3 . The broad profiles could be deconvoluted into four different peaks with maxima at 71.5, 73.0, 74.8 and $76.1 \mathrm{eV}$, which corresponded to different Pt oxidation states. The deconvoluted peaks centered at 73.0 and $76.1 \mathrm{eV}$ could be attributed to the $\mathrm{Pt}^{2+}$ [28], while those at 71.6 and $74.8 \mathrm{eV}$ were attributed to metallic Pt. The metallic state of platinum $\left(\mathrm{Pt}^{0}\right)$ would provide more suitable sites for ethanol electrooxidation than $\mathrm{Pt}^{2+}$ species [29], and the presence of $\mathrm{Pt}^{0}$ is essential for high ethanol electrooxidation rate.

Fig. 4 shows the $\mathrm{Sn} 3 d$ spectra profiles. $\mathrm{Pt}_{x}-\mathrm{Rh}_{y}-\mathrm{Sn}_{z} / \mathrm{C}$ catalysts have two peaks with binding energy at 487 and $495 \mathrm{eV}$ assigned to $\mathrm{Sn}^{4+}$ species for $3 \mathrm{~d}_{5 / 2}$ and $3 \mathrm{~d}_{3 / 2}$ transitions, respectively [30]. There are also other two small peaks at 485.5 and $493.8 \mathrm{eV}$, which correspond to metallic Sn [31]. These signals could come from the core of the $\mathrm{Sn}$ particles. The presence of $\mathrm{SnO}_{2}$ (and/or $\left.\mathrm{Sn}(\mathrm{OH})_{4}\right)$ in the catalyst agrees with results obtained by XRD.

The $\mathrm{Rh} 3 \mathrm{~d}_{5 / 2}$ and $3 \mathrm{~d}_{3 / 2}$ spectra profiles are displayed in Fig. 5. Metal rhodium usually appears at $\sim 307$ and $312 \mathrm{eV}$, while oxidized rhodium species at $\sim 309$ and $313.5 \mathrm{eV}$ [32]. For $\mathrm{Pt}_{x}-\mathrm{Rh}_{y}-$ $\mathrm{Sn}_{z} / \mathrm{C}$ - (T) catalysts oxidized Rh species are predominant on the surface, while for $\mathrm{Pt}_{x}-\mathrm{Rh}_{y}-\mathrm{Sn}_{z} / \mathrm{C}$ - (S) catalysts a major proportion of reduced Rh species are present.

Table 2 shows the percentage of the different Pt, Rh and Sn species calculated from the relative intensities of deconvoluted peaks observed in the XPS spectra. The areas under the different deconvoluted Pt, Rh and Sn peaks were quantified and normalized for all catalysts and the corresponding percentages calculated as a function of the total area. The results showed a prevailing presence of metallic Pt on the catalysts surface $(\sim 80 \%)$ for all samples studied. The 
fraction of oxidized Pt species ( $20 \%$ ) could be formed during catalyst exposure to the atmosphere, independently of the addition order of metal precursors. However, the percentage of reduced and oxidized Sn and Rh species depends on the preparation method. Oxidized surface species prevail in catalysts prepared by simultaneous co-precipitation, meanwhile the amount of reduced species on the surface is higher for catalysts prepared by sequential precipitation (see Table 2).

\subsubsection{CO stripping}

Fig. 6 shows CO stripping voltammograms of catalysts recorded at $10 \mathrm{mV} \mathrm{s}^{-1}$ in the supporting electrolyte at room temperature. Currents are expressed in terms of geometric surface area. The tests were carried out with the most active electrocatalysts for ethanol electrooxidation (see next section), that is, $\mathrm{Pt}_{3}-\mathrm{Rh}_{1}-\mathrm{Sn}_{4} / \mathrm{C}-(\mathbf{T})$ and $(\mathbf{S})$ and $\mathrm{Pt}_{6}-\mathrm{Rh}_{2}-\mathrm{Sn}_{4} / \mathrm{C}-(\mathbf{S})$, and with the reference $\mathrm{Pt} / \mathrm{C}$ electrocatalyst. There is a single peak CO stripping anodic wave for the Pt/C catalyst, with an onset $\mathrm{CO}$ oxidation potential at $0.70 \mathrm{~V}$ and a maximum of the oxidation peak at $0.82 \mathrm{~V}$. For $\mathrm{Pt}_{x-}$ $\mathrm{Rh}_{y}-\mathrm{Sn}_{z} / \mathrm{C}$ catalysts there are two anodic waves for CO stripping, with the onset CO oxidation close to $0.30 \mathrm{~V}$, and a broad stripping current peak at $0.55 \mathrm{~V}$. The lower potential on the $\mathrm{Pt}_{x}-\mathrm{Rh}_{y}-$ $\mathrm{Sn}_{z} / \mathrm{C}$ catalysts is attributed to the presence of oxygenated species on Sn sites that are formed at lower potentials compared to platinum [33,34], which allows the oxidation of $\mathrm{CO}$ to $\mathrm{CO}_{2}$ at lower potentials according to the bifunctional mechanism [35]. The higher intensity showed for $\mathrm{Pt}_{3}-\mathrm{Rh}_{1}-$ $\mathrm{Sn}_{4} / \mathrm{C}$ - (T) and (S) catalysts at lower potentials is directly related to the higher amount of Sn on the catalyst. Different peaks and/or shoulders presented by CO stripping voltammograms could also be related to heterogeneous sites on the catalyst surface. The electrochemical active surface (EAS) areas were estimated assuming that the normalized charge density for a monolayer of adsorbed carbon monoxide on polycrystalline platinum is $420 \mu \mathrm{C}^{*} \mathrm{~cm}^{-2}$ and that all platinum loaded on the working electrode is electrochemically active. The EAS values for $\mathrm{Pt}_{3}-\mathrm{Rh}_{1}-\mathrm{Sn}_{4} / \mathrm{C}$ - 
(T) and (S), $\mathrm{Pt}_{6}-\mathrm{Rh}_{2}-\mathrm{Sn}_{4} / \mathrm{C}$ - (S) and Pt/C catalysts were 33, 36, 37 and $21 \mathrm{~cm}^{2} \mathrm{~g}^{-1}$, respectively. An increase of EAS with the addition of Sn and Rh can be observed, so a higher amount of Pt is indeed available where the EAS value was increased with respect to Pt/C.

\subsection{Electrochemical experiments}

Fig. 7 shows cyclic voltammograms obtained in $0.5 \mathrm{M} \mathrm{H}_{2} \mathrm{SO}_{4}$ at a scan rate of $0.02 \mathrm{~V} \mathrm{~s}^{-1}$ (all catalysts), which show the typical behavior of hydrogen adsorption/desorption and oxide regions of Pt when in acidic solutions [36]. The adsorption/desorption of hydrogen between $0.05-0.40 \mathrm{~V}$ was seen for all catalysts, but this region was not well-defined for catalysts with high amount of Sn, i.e. $\mathrm{Pt}_{3}-\mathrm{Rh}_{1}-\mathrm{Sn}_{4} / \mathrm{C}$ - (T) and (S). The hydrogen-desorption region for $\mathrm{Pt}_{9}-\mathrm{Rh}_{3}-\mathrm{Sn}_{4} / \mathrm{C}-(\mathbf{S})$ was modified in comparison to $\mathrm{Pt}_{9}-\mathrm{Rh}_{3}-\mathrm{Sn}_{4} / \mathrm{C}-(\mathbf{T})$, which depends predominantly on the preparation method. Finally, the structure of peaks in the electrochemical profiles for $\mathrm{Pt}_{6}-\mathrm{Rh}_{2}-$ $\mathrm{Sn}_{4} / \mathrm{C}$ - (T) and (S) catalysts was similar, independently of the preparation method. The presence of tin oxides on the particle surface increases electrode capacitance producing a large value for the double-layer charging current $(0.4-0.7 \mathrm{~V})$, indicating that all the catalysts have a similar doublelayer charging current [37].

The electrocatalytic activities of the different catalysts during the oxidation of ethanol were compared by quasi-steady-state polarization and chronoamperometric measurements at room temperature. The anodic polarization curves of the catalysts in an ethanol-containing electrolyte showed in Fig. 8 indicate that the onset potential of ethanol electrooxidation using $\mathrm{Pt}_{x}-\mathrm{Rh}_{y}-\mathrm{Sn}_{z} / \mathrm{C}$ was shifted negatively by $\sim 0.2 \mathrm{~V}$ in comparison to Pt/C. For potentials lower than $0.55 \mathrm{~V}$, the

ternary $\mathrm{Pt}_{3}-\mathrm{Rh}_{1}-\mathrm{Sn}_{4} / \mathrm{C}$ - ( $\left.\mathbf{T}\right)$ possess the highest activity for ethanol electrooxidation, while for potentials higher than $0.55 \mathrm{~V}$, the highest electrochemical activity of the ternary catalysts was for 
$\mathrm{Pt}_{6}-\mathrm{Rh}_{2}-\mathrm{Sn}_{4} / \mathrm{C}-(\mathbf{S})$.

Notably, the electroactivity showed by catalysts with same composition, but with different preparation methodology, was lower for $\mathrm{Pt}_{3}-\mathrm{Rh}_{1}-\mathrm{Sn}_{4} / \mathrm{C}$ - (S) and $\mathrm{Pt}_{6}-\mathrm{Rh}_{2}-\mathrm{Sn}_{4} / \mathrm{C}$ - (T), than for $\mathrm{Pt}_{3}-\mathrm{Rh}_{1}-\mathrm{Sn}_{4} / \mathrm{C}$ - (T) and $\mathrm{Pt}_{6}-\mathrm{Rh}_{2}-\mathrm{Sn}_{4} / \mathrm{C}$ - (S), respectively. On the contrary,Pt9-Rh $3-\mathrm{Sn}_{4} / \mathrm{C}-(\mathbf{T})$ and (S) catalysts presented the same anodic polarization curves on the potential range studied. This behavior points out an important dependence between the metal precursors addition order and the composition of the ternary $\mathrm{Pt}_{x}-\mathrm{Rh}_{y}-\mathrm{Sn}_{z} / \mathrm{C}$ catalysts. A comparison of results obtained for binary catalysts $\left(\mathrm{Pt}_{2}-\mathrm{Sn}_{1} / \mathrm{C}\right.$ and $\left.\mathrm{Pt}_{3}-\mathrm{Rh}_{1} / \mathrm{C}\right)$ and $\mathrm{Rh}$-containing catalysts is displayed in Fig. 9, and a synergic effect between Pt, Sn and Rh can be seen. Fig. 9 shows that the presence of Rh on the $\mathrm{Pt}_{2}-\mathrm{Sn}_{1} / \mathrm{C}$ catalyst leads to a substantial enhancement in the catalytic activity towards ethanol electrooxidation, in agreement with results reported by different authors [18,19].

In the electrooxidation of ethanol at low temperature in acid environment [38] with platinum catalysts, the ability for $\mathrm{C}-\mathrm{C}$ bond cleavage and $\mathrm{CO}$ oxidation are established as the ratedetermining steps. Therefore, a synergic effect among all these three metals would be largely effective towards electrooxidation, as shown in Fig. 10, for chronoamperometry measurements performed at $0.5 \mathrm{~V}$ for $\mathrm{Pt}_{x}-\mathrm{Rh}_{y}-\mathrm{Sn}_{z} / \mathrm{C}$ catalysts. During the first seconds, there was a sharp decrease in the current density, followed by a slow decrease in the current density and a steadystate current was observed for all catalysts after $\sim 400 \mathrm{~s}$. This can be explained by the fact that, at first, dehydrogenation of ethanol occurs irreversibly on Pt sites leading to strongly adsorbed intermediates. Then, it seems that Sn favors CO-O coupling and also the oxidation of other adsorbed intermediates by providing oxygen, producing higher electrochemical currents. Rh modifies the Pt electronic properties and facilitates cleavage of $\mathrm{C}-\mathrm{C}$ bonds.

The chronoamperometric curve for Pt/C displays a faster decrease than those for the other catalysts. The $\mathrm{Pt}_{6}-\mathrm{Rh}_{2}-\mathrm{Sn}_{4} / \mathrm{C}$ - (S) catalyst presented higher activity, whereas similar behaviors 
for the $\mathrm{Pt}_{3}-\mathrm{Rh}_{1}-\mathrm{Sn}_{4} / \mathrm{C}$ - (T) and $\mathrm{Pt}_{3}-\mathrm{Rh}_{1}-\mathrm{Sn}_{4} / \mathrm{C}$ - (S) catalysts were seen. The lowest activity was presented by $\mathrm{Pt}_{6}-\mathrm{Rh}_{2}-\mathrm{Sn}_{4} / \mathrm{C}-(\mathbf{T}), \mathrm{Pt}_{9}-\mathrm{Rh}_{3}-\mathrm{Sn}_{4} / \mathrm{C}-(\mathbf{T})$ and $(\mathbf{S})$ catalysts. A clear difference is displayed between $\mathrm{Pt}_{6}-\mathrm{Rh}_{2}-\mathrm{Sn}_{4} / \mathrm{C}$ - (S) and (T) catalysts. After 600 s, the $\mathrm{Pt}_{6}-\mathrm{Rh}_{2}-\mathrm{Sn}_{4} / \mathrm{C}$ - (S) catalyst displayed a value of pseudo-current density four times greater than that of $\mathrm{Pt}_{6}-\mathrm{Rh}_{2}-\mathrm{Sn}_{4} / \mathrm{C}$ - $(\mathbf{T})\left(\mathrm{j}=\sim 80 \mathrm{~A}^{*} \mathrm{~cm}^{-2 *} \mathrm{gPt}^{-1}\right.$ versus $\left.\mathrm{j}=\sim 20 \mathrm{~A}^{*} \mathrm{~cm}^{-2 *} \mathrm{~g}_{\mathrm{Pt}}{ }^{-1}\right)$. Therefore, in accordance with the anodic polarization curves, there is a strong dependence between the metal precursors addition orders on the ternary $\mathrm{Pt}_{x}-\mathrm{Rh}_{y}-\mathrm{Sn}_{z} / \mathrm{C}$ catalysts and the catalytic activity towards ethanol oxidation.

The XRD, TEM and XPS results showed that nanometer-sized noble metal catalysts can be easily prepared by two methods adopted here and both are suitable to prepare supported Pt-RhSn-based catalysts with high metal loading. On the another hand, both the composition and the metal precursors addition order of the ternary $\mathrm{Pt}_{x}-\mathrm{Rh}_{y}-\mathrm{Sn}_{z} / \mathrm{C}$ catalysts could modify the cooperative effect of $\mathrm{Rh}$ and $\mathrm{Sn}$ in the vicinity of Pt sites, and therefore could provide, or not, a high activity for ethanol oxidation and better tolerance towards poisoning species. The high activity of the $\mathrm{Pt}_{6}-\mathrm{Rh}_{2}-\mathrm{Sn}_{4} / \mathrm{C}$ - (S) and $\mathrm{Pt}_{3}-\mathrm{Rh}_{1}-\mathrm{Sn}_{4} / \mathrm{C}-(\mathbf{T})$ catalysts is attributed not only to the bifunctional effect of Pt and Sn (Pt provides active sites and Sn provides oxygenated species to oxidize the intermediates), but also to the electronic structure modified by ternary composition that facilitates $\mathrm{C}-\mathrm{C}$ bonds cleavage, increasing the current density. It is worth to note that $\mathrm{Rh}$ is more expensive than Pt, and its use at low concentration can be justified because it increases the activity towards the electroxidation of ethanol.

While all the electrocatalysts investigated exhibited catalytic activity for ethanol oxidation, the most active one had the composition Pt:Rh:Sn = 6:2:4 atomic ratio prepared with addition of metals separately (first Rh, and Pt-Sn afterwards). 


\section{Conclusions}

A simple route was used to synthetize ternary $\mathrm{Pt}_{x}-\mathrm{Rh}_{y}-\mathrm{Sn}_{z} / \mathrm{C}$ anode catalysts with different atomic ratio, by reduction of $\mathrm{Pt}, \mathrm{Rh}$ and $\mathrm{Sn}$ precursors in different addition order using formic acid as reducing agent. The highest content of $\mathrm{Sn}$ used in the catalysts $\left(\mathrm{Pt}_{3}-\mathrm{Rh}_{1}-\mathrm{Sn}_{4} / \mathrm{C}\right)$ results in high catalytic activity towards ethanol oxidation at low potentials $(<0.55 \mathrm{~V})$, independently of the synthesis methodology. This is attributed to the fact that Sn provides oxygenated species to oxidize the intermediates. Alternatively, the activity of $\mathrm{Pt}_{6}-\mathrm{Rh}_{2}-\mathrm{Sn}_{4} / \mathrm{C}$ catalysts strongly depends on the synthesis conditions. The sequential reductive precipitation (two-steps) resulted in a major proportion of reduced Rh species and the highest catalytic activity at high potentials ( $>0.55 \mathrm{~V})$. Possibly, the enhanced activity can be attributed to the Pt electronic structure modification by Rh, which facilitates $\mathrm{C}-\mathrm{C}$ bonds cleavage. Thus, the Pt crystal structure and the distribution $\mathrm{Sn}$ and Rh species on the catalyst surface depend on the preparation method. A correlation between the metal addition order and the composition of the ternary $\mathrm{Pt}_{x}-\mathrm{Rh}_{y}-\mathrm{Sn}_{z} / \mathrm{C}$ catalysts towards ethanol electrooxidation was found. The catalytic properties of this ternary electrocatalyst might play an important role in ethanol oxidation, and this was attributed to the synergistic effect between all three constituents.

\section{Acknowledgments}

The authors thank the Brazilian National Council of Technological and Scientific DevelopmentCNPq (grants: 402243/2012-9, 303630/2012-4, 474261/2013-1, 407274/2013-8 and 310282/20136) for the scholarships and financial support for this work.

\section{References}


1. Lamy C, Rousseau S, Belgsir E, Coutanceau C, Léger J-M (2004) Recent progress in the direct ethanol fuel cell: development of new platinum-tin electrocatalysts. Electrochim. Acta 49 (22):3901-3908

2. Antolini E (2007) Catalysts for direct ethanol fuel cells. J. Power Sources 170 (1):1-12

3. De Souza J, Queiroz S, Bergamaski K, Gonzalez E, Nart F (2002) Electro-oxidation of ethanol on Pt, Rh, and PtRh electrodes. A study using DEMS and in-situ FTIR techniques. J. Phys. Chem. B 106 (38):9825-9830

4. Camara G, Iwasita T (2005) Parallel pathways of ethanol oxidation: The effect of ethanol concentration. J. Electroanal. Chem. 578 (2):315-321

5. Xia X, Liess H-D, Iwasita T (1997) Early stages in the oxidation of ethanol at low index single crystal platinum electrodes. J. Electroanal. Chem. 437 (1):233-240

6. Lamy C, Lima A, LeRhun V, Delime F, Coutanceau C, Léger J-M (2002) Recent advances in the development of direct alcohol fuel cells (DAFC). J. Power Sources 105 (2):283-296

7. Dubau L, Hahn F, Coutanceau C, Léger J-M, Lamy C (2003) On the structure effects of bimetallic PtRu electrocatalysts towards methanol oxidation. J J. Electroanal. Chem. 554:407-415

8. Prater KB (1996) Solid polymer fuel cells for transport and stationary applications. J. Power Sources 61 (1):105-109

9. Simões F, Dos Anjos D, Vigier F, Léger J-M, Hahn F, Coutanceau C, Gonzalez E, TremiliosiFilho G, De Andrade A, Olivi P (2007) Electroactivity of tin modified platinum electrodes for ethanol electrooxidation. J. Power Sources 167 (1):1-10

10. Colmati F, Antolini E, Gonzalez E (2008) Preparation, structural characterization and activity for ethanol oxidation of carbon supported ternary Pt-Sn-Rh catalysts. J J. Alloy. Compd. 456 (1):264-270

11. Vigier F, Coutanceau C, Perrard A, Belgsir E, Lamy C (2004) Development of anode catalysts for a direct ethanol fuel cell. J. Appl. Electrochem. 34 (4):439-446

12. Neto AO, Giz M, Perez J, Ticianelli E, Gonzalez E (2002) The electro-oxidation of ethanol on $\mathrm{Pt}-\mathrm{Ru}$ and Pt-Mo particles supported on high-surface-area carbon. J. Electrochem. Soc. 149 (3):A272-A279

13. González Pereira M, Dávila Jiménez M, Elizalde M, Manzo-Robledo A, Alonso-Vante N (2004) Study of the electrooxidation of ethanol on hydrophobic electrodes by DEMS and HPLC. Electrochim. Acta 49 (22):3917-3925

14. Camara G, De Lima R, Iwasita T (2004) Catalysis of ethanol electrooxidation by PtRu: the influence of catalyst composition. Electrochem. Commun. 6 (8):812-815 
15. Du W, Wang Q, LaScala CA, Zhang L, Su D, Frenkel AI, Mathur VK, Teng X (2011) Ternary PtSnRh-SnO 2 nanoclusters: synthesis and electroactivity for ethanol oxidation fuel cell reaction. J. Mater. Chem. 21 (24):8887-8892

16. Song S, He C, Liu J, Wang Y, Brouzgou A, Tsiakaras P (2012) Two-step sequence for synthesis of efficient PtSn@Rh/C catalyst for oxidizing ethanol and intermediate products. Appl. Catal. BEnviron.119:227-233

17. Li M, Cullen DA, Sasaki K, Marinkovic NS, More K, Adzic RR (2012) Ternary Electrocatalysts for Oxidizing Ethanol to Carbon Dioxide: Making Ir Capable of Splitting C-C Bond. J. Am. Chem. Soc. 135 (1):132-141

18. Kowal A, Li M, Shao M, Sasaki K, Vukmirovic M, Zhang J, Marinkovic N, Liu P, Frenkel A, Adzic R (2009) Ternary Pt/Rh/SnO 2 electrocatalysts for oxidizing ethanol to $\mathrm{CO}_{2}$. Nat. Mater 8 (4):325-330

19. Li M, Kowal A, Sasaki K, Marinkovic N, Su D, Korach E, Liu P, Adzic R (2010) Ethanol oxidation on the ternary Pt-Rh-SnO/C electrocatalysts with varied Pt: Rh: Sn ratios. Electrochim. Acta 55 (14):4331-4338

20. Kowal A, Gojković SL, Lee K-S, Olszewski P, Sung Y-E (2009) Synthesis, characterization and electrocatalytic activity for ethanol oxidation of carbon supported Pt, Pt-Rh, Pt-SnO 2 and Pt$\mathrm{Rh}-\mathrm{SnO}_{2}$ nanoclusters. Electrochem. Commun. 11 (4):724-727

21. Jones GS, Mavrikakis M, Barteau MA, Vohs JM (1998) First synthesis, experimental and theoretical vibrational spectra of an oxametallacycle on a metal surface. J. Am. Chem. Soc. 120 (13):3196-3204

22. Lima F, Gonzalez E (2008) Ethanol electro-oxidation on carbon-supported Pt-Ru, Pt-Rh and Pt-Ru-Rh nanoparticles. Electrochim. Acta 53 (6):2963-2971

23. Wang Y, Song S, Andreadis G, Liu H, Tsiakaras P (2011) Understanding the electrocatalytic activity of $\mathrm{Pt}<\mathrm{sub}>\mathrm{x}</$ sub $>\mathrm{Sn}<\mathrm{sub}>\mathrm{y}</$ sub $>$ in direct ethanol fuel cells. J. Power Sources 196 (11):4980-4986

24. Zhou W, Zhou Z, Song S, Li W, Sun G, Tsiakaras P, Xin Q (2003) Pt based anode catalysts for direct ethanol fuel cells. Appl. Catal. B-Environ. 46 (2):273-285

25. Silva J, De Souza R, Parreira L, Neto ET, Calegaro M, Santos M (2010) Ethanol oxidation reactions using $\mathrm{SnO}_{2} @ \mathrm{Pt} / \mathrm{C}$ as an electrocatalyst. Appl. Catal. B-Environ. 99 (1):265-271

26. Colmati F, Antolini E, Gonalez ER (2007) Ethanol oxidation on carbon supported Pt-Sn electrocatalysts prepared by reduction with formic acid. J. Electrochem. Soc. 154 (1):B39-B47

27. Colmati F, Antolini E, Gonzalez ER (2007) Ethanol oxidation on a carbon-supported $\mathrm{Pt}<\mathrm{sub}>$ $75</$ sub $>\mathrm{Sn}<\mathrm{sub}>25</$ sub $>$ electrocatalyst prepared by reduction with formic acid: Effect of thermal treatment. Appl. Catal. B-Environ. 73 (1):106-115 
28. Sun S, Yang D, Villers D, Zhang G, Sacher E, Dodelet J-P (2008) Template- and Surfactantfree Room Temperature Synthesis of Self- Assembled 3D Pt Nanoflowers from Single- Crystal Nanowires. Adv. Mater. 20 (3):571-574

29. Park K-W, Choi J-H, Lee S-A, Pak C, Chang H, Sung Y-E (2004) PtRuRhNi nanoparticle electrocatalyst for methanol electrooxidation in direct methanol fuel cell. J. Catalysis 224 (2):236242

30. Shukla A, Arico A, El-Khatib K, Kim H, Antonucci P, Antonucci V (1999) An X-ray photoelectron spectroscopic study on the effect of Ru and Sn additions to platinised carbons. Appl. Surf. Sci. 137 (1):20-29

31. Zignani S, Gonzalez E, Baglio V, Siracusano S, Aricò A (2012) Investigation of a Pt3Sn/C Electro-Catalyst in a Direct Ethanol Fuel Cell Operating at Low Temperatures for Portable Applications. Int. J. Electrochem. Sci. 7:3155-3166

32. Hakeem AA, Rajendran J, Kapteijn F, Makkee M (2015) Effect of rhodium on the water-gas shift performance of Fe $2 \mathrm{O}$ 3/ZrO 2 and $\mathrm{CeO}$ 2/ZrO 2: Influence of rhodium precursor. Catal. Today 242:168-177

33. Morimoto Y, Yeager EB (1998) CO oxidation on smooth and high area Pt, Pt-Ru and Pt-Sn electrodes. J. Electroanal. Chem. 441 (1):77-81

34. Wang K, Gasteiger H, Markovic N, Ross P (1996) On the reaction pathway for methanol and carbon monoxide electrooxidation on Pt-Sn alloy versus Pt-Ru alloy surfaces. Electrochim. Acta 41 (16):2587-2593

35. Gasteiger HA, Markovic N, Ross Jr PN, Cairns EJ (1994) Carbon monoxide electrooxidation on well-characterized platinum-ruthenium alloys. J. Phys. Chem. 98 (2):617-625

36. Stevens D, Dahn J (2003) Electrochemical characterization of the active surface in carbonsupported platinum electrocatalysts for PEM fuel cells. J. Electrochem. Soc. 150 (6):A770-A775

37. Chang SC, Leung LWH, Weaver MJ (1990) Metal crystallinity effects in electrocatalysis as probed by real-time FTIR spectroscopy: electrooxidation of formic acid, methanol, and ethanol on ordered low-index platinum surfaces. J. Phy. Chem. 94 (15):6013-6021

38. Kua J, Goddard WA (1999) Oxidation of methanol on 2nd and 3rd row group VIII transition metals (Pt, Ir, Os, Pd, Rh, and Ru): application to direct methanol fuel cells. J. Am. Chem. Soc. 121 (47):10928-10941 


\section{Figure captions}

Fig. 1. X-ray diffractograms of samples over the scan range $10-90^{\circ}$. (a) Catalyst prepared by sequential precipitation, $\mathrm{Pt}_{x}-\mathrm{Rh}_{y}-\mathrm{Sn}_{z} / \mathrm{C}$ - (S) and, (b) Pt and Sn co-precipitated, $\mathrm{Pt}_{x}-\mathrm{Rh}_{y}-\mathrm{Sn}_{z} / \mathrm{C}$ (T).

Fig. 2. TEM images and histogram of particle size distribution determined from TEM of Pt/C (a) $\mathrm{Pt}_{3}-\mathrm{Rh}_{1}-\mathrm{Sn}_{4} / \mathrm{C}$ - (T), (b) Pt6-Rh2 $6 \mathrm{Sn}_{4} / \mathrm{C}$ - (T), (c) Pt9-Rh33-Sn 4 /C - (T), (d) Pt3 $-\mathrm{Rh}_{1}-\mathrm{Sn}_{4} / \mathrm{C}$ - (S), (e) $\mathrm{Pt}_{6}-\mathrm{Rh}_{2}-\mathrm{Sn}_{4} / \mathrm{C}$ - (S), and (f) $\mathrm{Pt}_{9}-\mathrm{Rh}_{3}-\mathrm{Sn}_{4} / \mathrm{C}$ - (S) catalysts.

Fig. 3. Pt $4 \mathrm{f}$ transition in XPS experiments performed with catalysts.

Fig. 4. Sn 3d transition in XPS experiments performed with catalysts.

Fig. 5. Rh 3d transition in XPS experiments performed with catalysts.

Fig. 6. CO stripping experiments recorded at $0.01 \mathrm{~V} \mathrm{~s}^{-1}$.

Fig. 7. Cyclic voltammetry curves for electrocatalysts in $0.5 \mathrm{M} \mathrm{H}_{2} \mathrm{SO}_{4}$ electrolyte. Scan rate of $0.02 \mathrm{~V} \mathrm{~s}^{-1}$ at room temperature. (a) Catalyst prepared by sequential precipitation, $\mathrm{Pt}_{x}-\mathrm{Rh}_{y}-\mathrm{Sn}_{z} / \mathrm{C}$ (S) and, (b) Pt and Sn co-precipitated, $\mathrm{Pt}_{x}-\mathrm{Rh}_{y}-\mathrm{Sn}_{z} / \mathrm{C}-(\mathbf{T})$.

Fig. 8. Anode polarization profiles for the oxidation of ethanol in $0.50 \mathrm{M} \mathrm{C}_{2} \mathrm{H}_{5} \mathrm{OH} / 0.5 \mathrm{M} \mathrm{H}_{2} \mathrm{SO}_{4}$ solutions at room temperature taken on the ternary electrocatalysts developed.

Fig. 9. Comparison of anode polarization profiles for the oxidation of ethanol in $0.50 \mathrm{M}$ $\mathrm{C}_{2} \mathrm{H}_{5} \mathrm{OH} / 0.5 \mathrm{M} \mathrm{H}_{2} \mathrm{SO}_{4}$ solution at room temperature for samples with Rh or without $\mathrm{Rh}$.

Fig. 10. Chronoamperometric curves for the oxidation of ethanol in $0.5 \mathrm{M} \mathrm{C}_{2} \mathrm{H}_{5} \mathrm{OH} / 0.5 \mathrm{M} \mathrm{H}_{2} \mathrm{SO}_{4}$ 
solution at $0.5 \mathrm{~V}$ versus RHE at room temperature taken on the ternary electrocatalysts developed. 


\section{Table 1}

Structural characteristic obtained from XRD, TEM and EDS.

\begin{tabular}{cccc}
\hline Catalyst & $\begin{array}{c}\text { Particle size } \\
(\mathrm{nm})^{\mathrm{a}}\end{array}$ & $\begin{array}{c}\text { Lattice } \\
\text { parameter }(\mathrm{nm})\end{array}$ & $\begin{array}{c}\text { Average particle } \\
\text { size from TEM } \\
(\mathrm{nm})\end{array}$ \\
\hline $\mathrm{Pt} / \mathrm{C}$ & 3.8 & 0.3914 & $3.89 \pm 1.04$ \\
$\mathrm{Pt}_{3}-\mathrm{Rh}_{1}-\mathrm{Sn}_{4}-(\mathrm{T})$ & 2.6 & 0.3955 & $2.75 \pm 0.69$ \\
$\mathrm{Pt}_{6}-\mathrm{Rh}_{2}-\mathrm{Sn}_{4}-(\mathrm{T})$ & 2.8 & 0.3918 & $3.04 \pm 0.82$ \\
$\mathrm{Pt}_{9}-\mathrm{Rh}_{3}-\mathrm{Sn}_{4}-(\mathrm{T})$ & 2.8 & 0.3925 & $3.26 \pm 0.80$ \\
$\mathrm{Pt}_{3}-\mathrm{Rh}_{1}-\mathrm{Sn}_{4}-(\mathrm{S})$ & 2.8 & 0.3983 & $2.98 \pm 0.86$ \\
$\mathrm{Pt}_{6}-\mathrm{Rh}_{2}-\mathrm{Sn}_{4}-(\mathrm{S})$ & 2.8 & 0.3945 & $3.45 \pm 0.78$ \\
$\mathrm{Pt}_{9}-\mathrm{Rh}_{3}-\mathrm{Sn}_{4}-(\mathrm{S})$ & 2.8 & 0.3924 & $3.70 \pm 0.66$ \\
\hline
\end{tabular}

${ }^{a}$ Calculated from Pt (220) peak with the Scherrer's formula.

${ }^{\mathrm{b}}$ Nominal percentage. 
Table 2

Percentage of different Pt and Sn species observed from the XPS data and EAS values.

\begin{tabular}{ccccc}
\hline Catalyst & $\begin{array}{c}\mathrm{Pt}^{0} / \mathrm{Pt}^{2+} \text { species } \\
(\%)\end{array}$ & $\begin{array}{c}\mathrm{Sn}^{0} / \mathrm{Sn}^{2+} \text { species } \\
(\%)\end{array}$ & $\begin{array}{c}\mathrm{Rh}^{0} / \mathrm{Rh}^{3+} \text { species } \\
(\%)\end{array}$ & ${\mathrm{EAS}\left(\mathrm{m}^{2} \mathrm{gPt}^{-1}\right)^{\mathrm{a}}}$ \\
\hline $\mathrm{Pt} / \mathrm{C}$ & $85 / 15$ & - & - & 13 \\
$\mathrm{Pt}_{3}-\mathrm{Rh}_{1}-\mathrm{Sn}_{4}-(\mathrm{T})$ & $70 / 30$ & $5 / 95$ & - & 31 \\
$\mathrm{Pt}_{6}-\mathrm{Rh}_{2}-\mathrm{Sn}_{4}-(\mathrm{T})$ & $82 / 18$ & $5 / 95$ & $38 / 62$ & - \\
$\mathrm{Pt}_{9}-\mathrm{Rh}_{3}-\mathrm{Sn}_{4}-(\mathrm{T})$ & $82 / 18$ & $10 / 90$ & $25 / 75$ & - \\
\hline $\mathrm{Pt}_{3}-\mathrm{Rh}_{1}-\mathrm{Sn}_{4}-(\mathrm{S})$ & $80 / 20$ & $13 / 87$ & $53 / 47$ & - \\
\hline $\mathrm{Pt}_{6}-\mathrm{Rh}_{2}-\mathrm{Sn}_{4}-(\mathrm{S})$ & $82 / 18$ & $10 / 90$ & $60 / 40$ & 32 \\
\hline $\mathrm{Pt}_{9}-\mathrm{Rh}_{3}-\mathrm{Sn}_{4}-(\mathrm{S})$ & $80 / 20$ & $14 / 86$ & $60 / 40$ &
\end{tabular}

${ }^{a}$ Calculated from CO stripping experiments assuming that the normalized charge density for a monolayer of adsorbed carbon monoxide on polycrystalline platinum is $420 \mu \mathrm{C} * \mathrm{~cm}^{-2}$ 

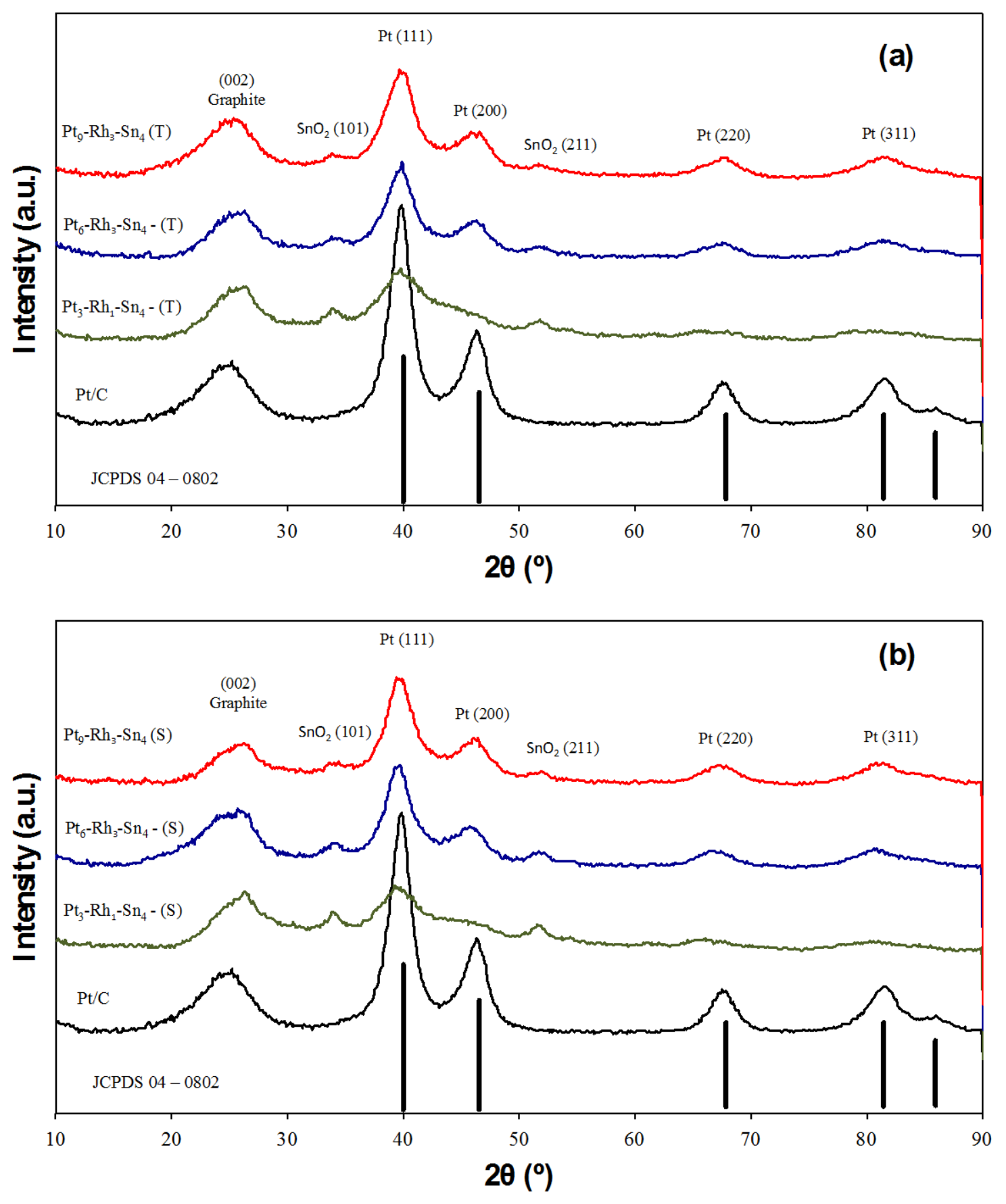

Figure 1. 

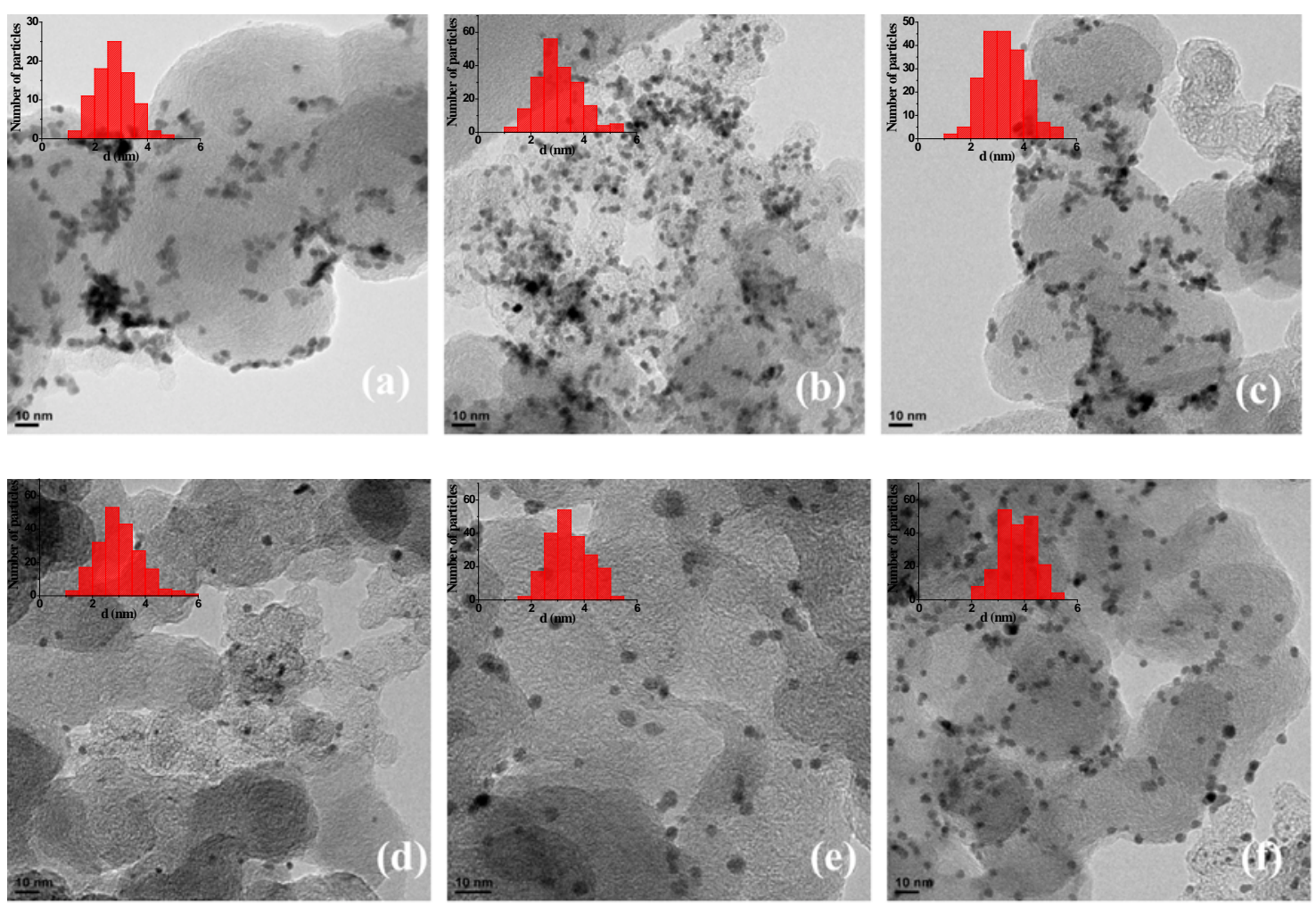

Figure 2. 

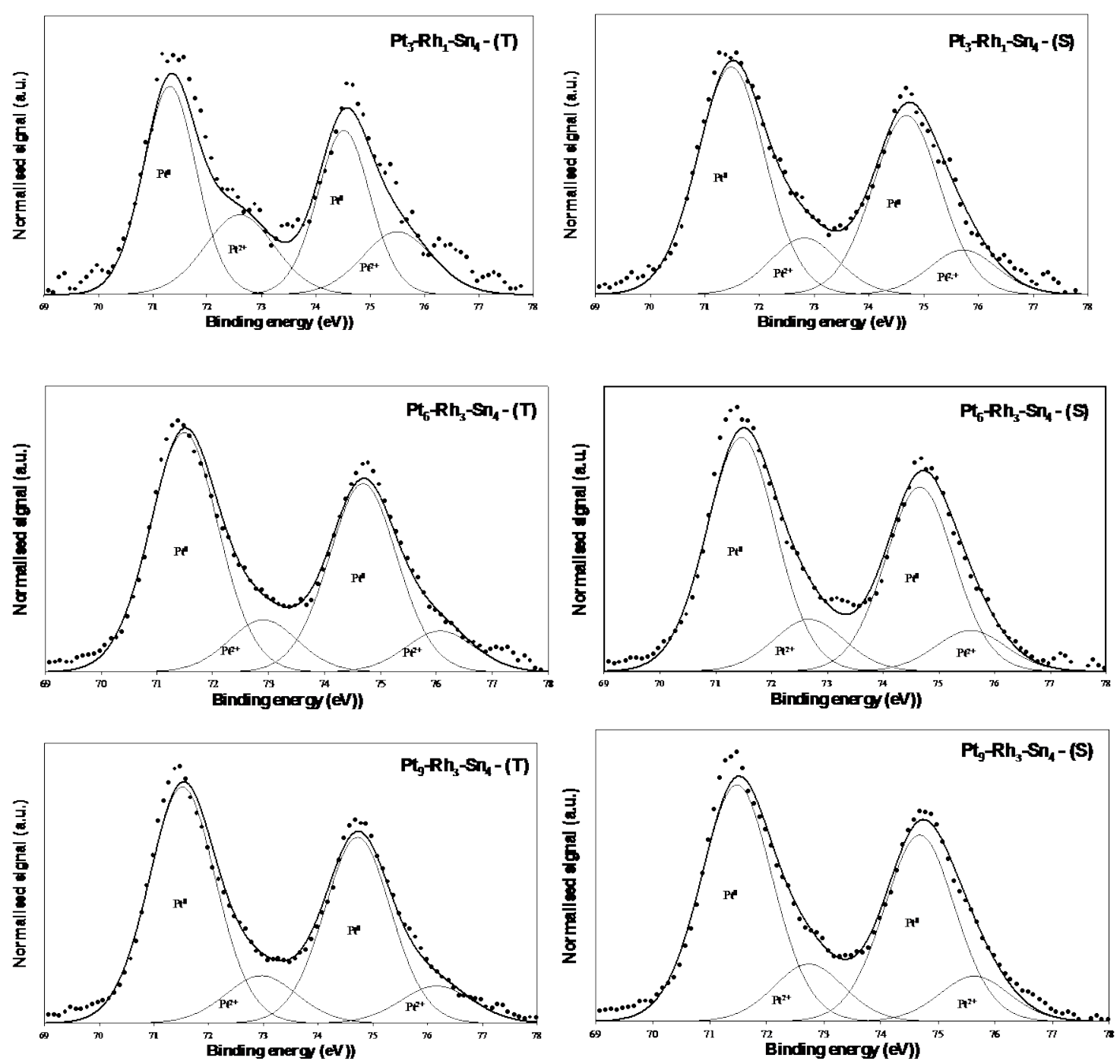

Figure 3. 

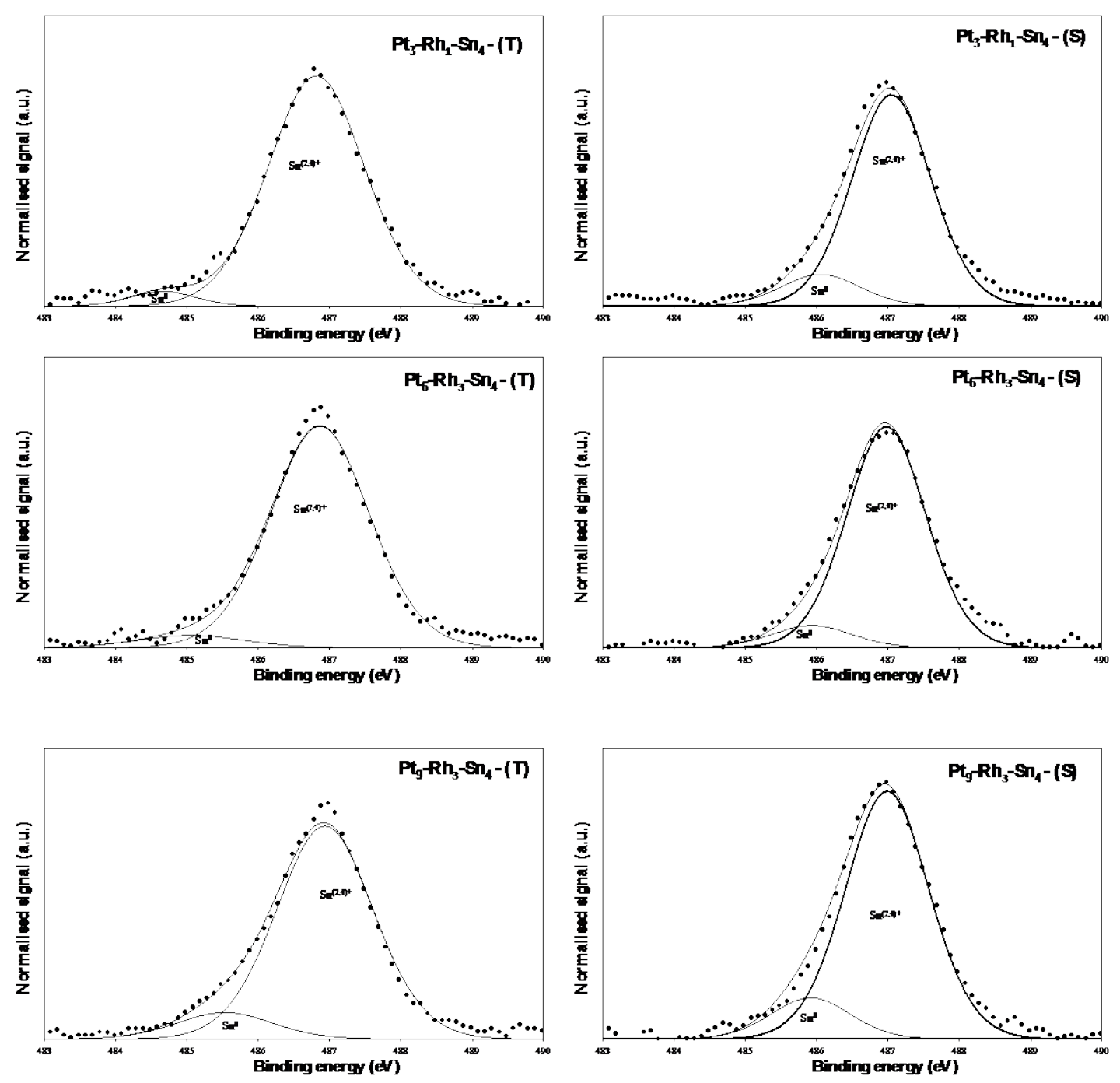

Figure 4. 

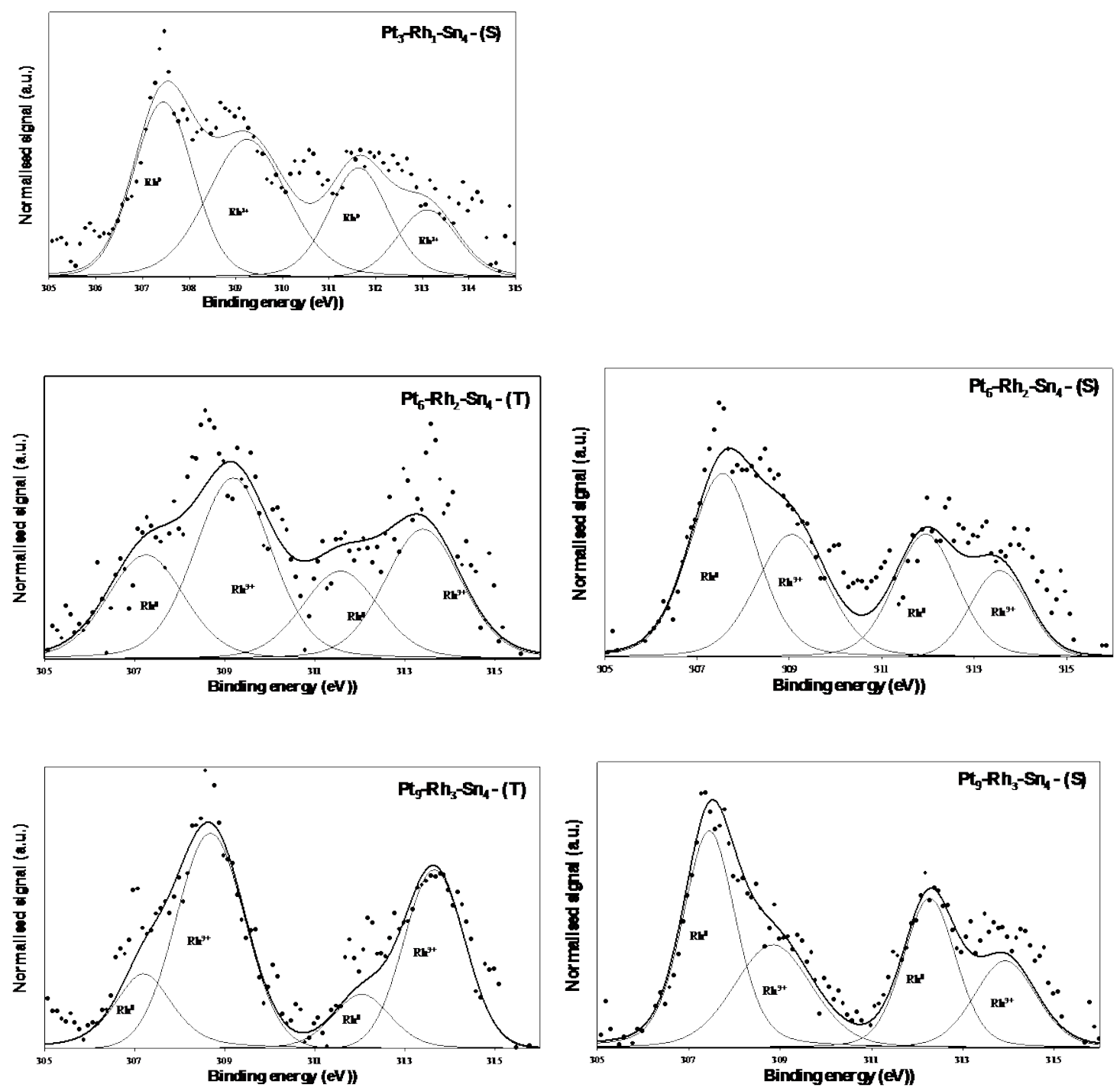

Figure 5. 


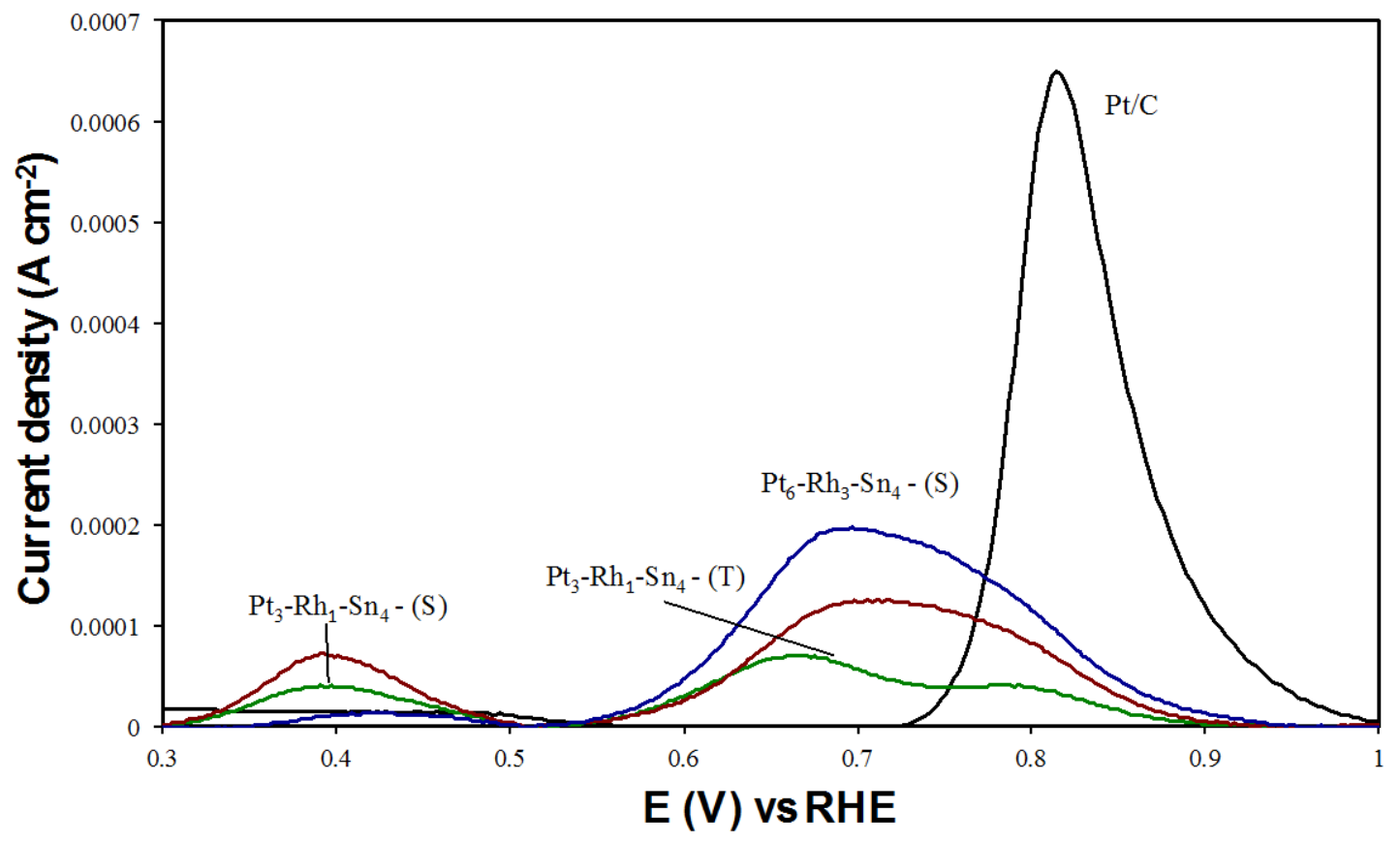

Figure 6. 

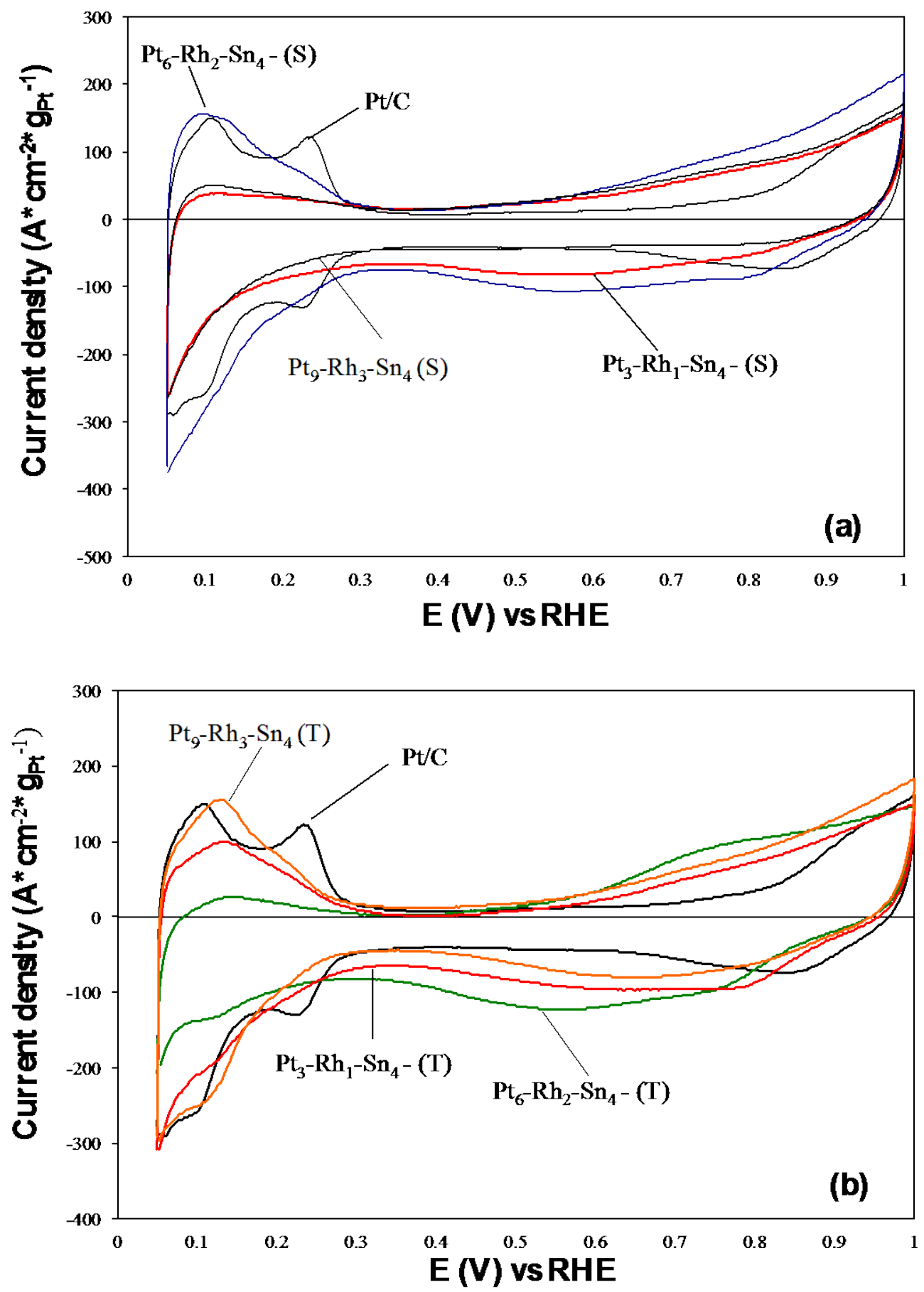

Figure 7. 


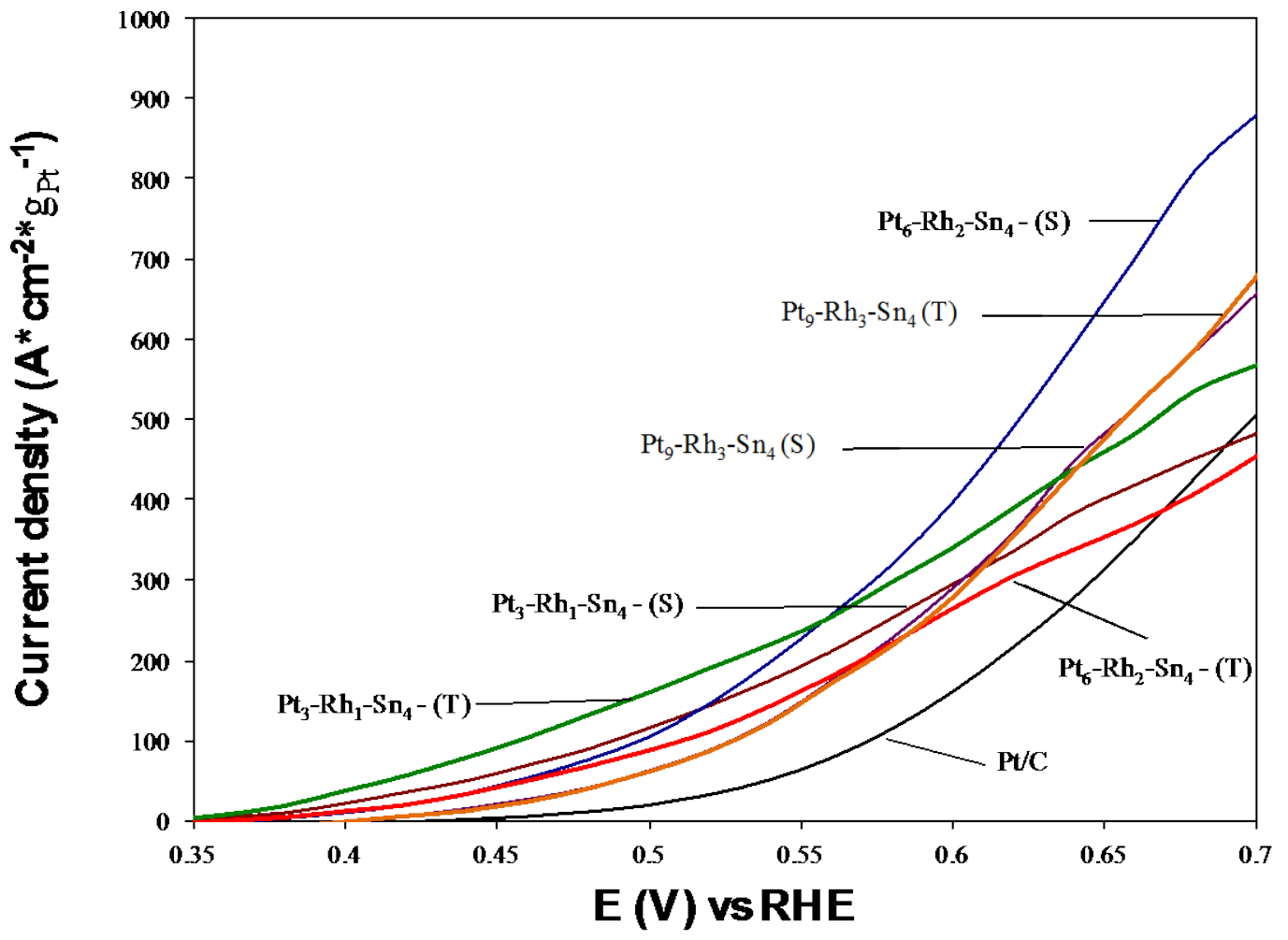

Figure 8. 


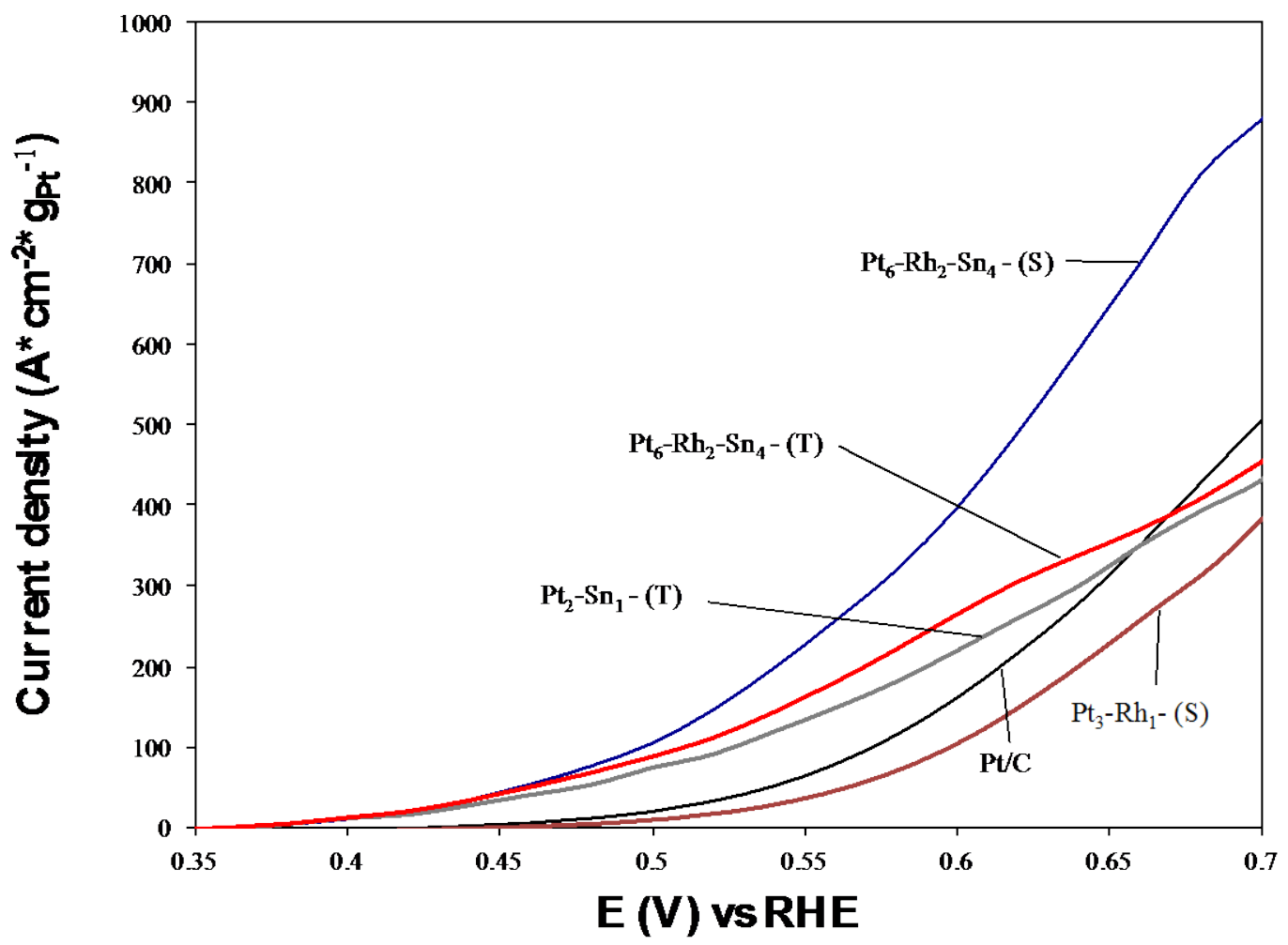

Figure 9. 


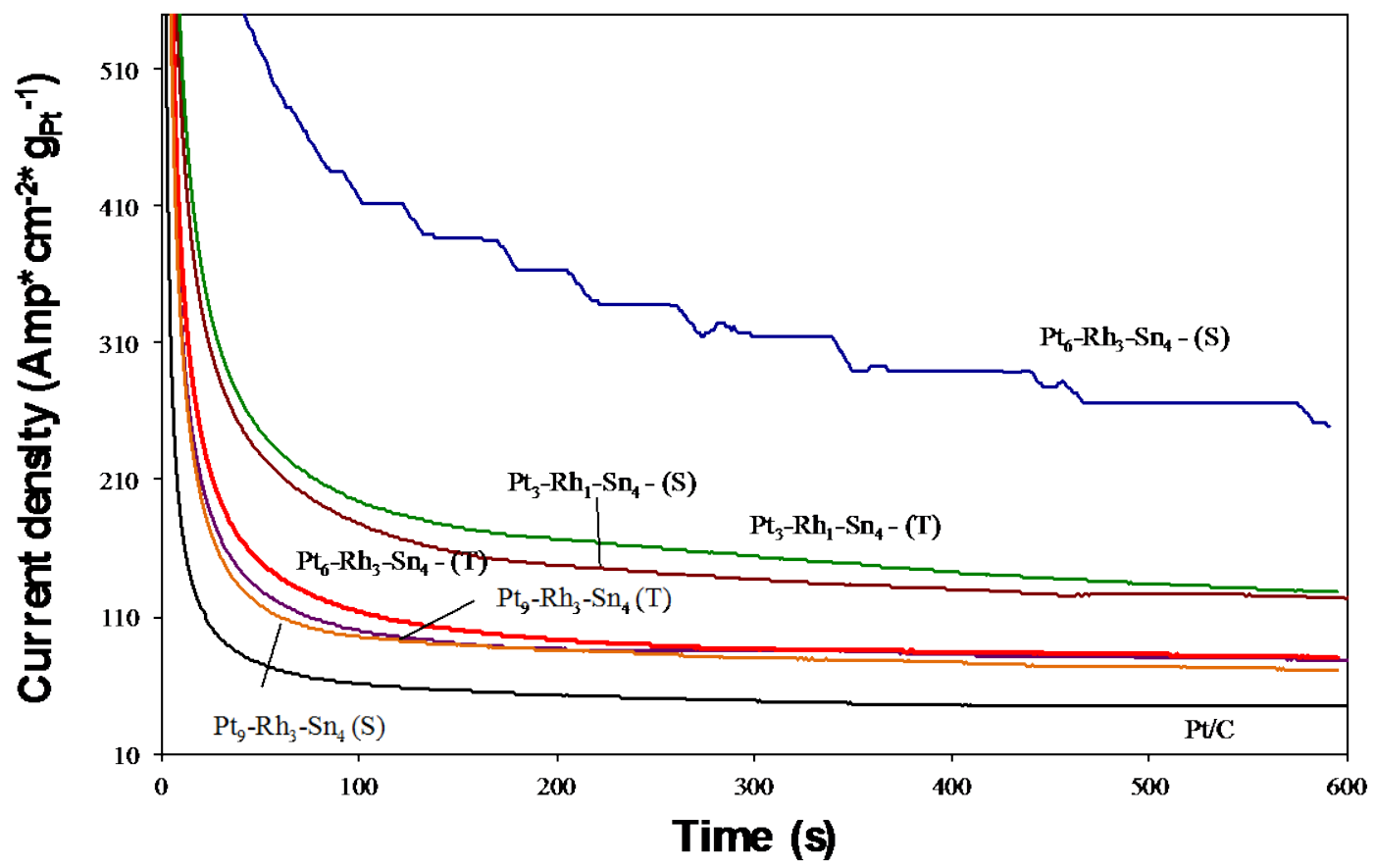

Figure 10. 